\title{
Perspective Formats for the Development of Decorative and Applied Art of the Indigenous Peoples of the Krasnoyarsk Territory
}

\author{
Ksenia V. Reznikova*, Nataliya N. Seredkina* \\ and Yulia S. Zamaraeva \\ Siberian Federal University \\ 79 Svobodny, Krasnoyarsk, 660041, Russia
}

Received 01.06.2017, received in revised form 03.10.2017, accepted 10.10.2017

The article analyzes contemporary decorative and applied art of the indigenous peoples of the Krasnoyarsk Territory (Selkups, Yessey Yakuts, Nenets, Nganasans, Dolgans), in order to reveal perspective formats for the development of this cultural practice. The authors have obtained empirical data using methods of participant observation and expert in-depth interview during field research in historical places of the Krasnoyarsk Territory - in Noska, Farkovo, Dudinka, Khatanga, Yessey, etc. As a result, they allocated the main trends of contemporary decorative and applied art of the indigenous peoples in the territory that, on the one hand, are associated with partial preservation of traditional occupations (tailoring, shoe making, beadwork), the emergence of new practices of decorative and applied art (pike head finishing), and on the other hand, are connected with the loss of knowledge, mastery, tradition of transferring skills in the manufacture of items of decorative and applied art from generation to generation. In addition, on the basis of the analysis of the current situation in the field of decorative and applied art of the indigenous peoples of the Krasnoyarsk Territory, the authors singled out a number of promising formats for the development of this practice of culture that are already used by the indigenous peoples and those that could be effectively used in the future.

Keywords: decorative and applied art, Nenets, Selkups, Dolgans, Yessey Yakuts, Nganasans.

The study was funded by the Krasnoyarsk Region Science and Technology Support Fund in accordance with the research project "Decorative and Applied Art of the Indigenous Peoples of the Krasnoyarsk Territory: Current Status, Prospects for Development".

The study was funded by the Russian Foundation for Basic Research, Government of the Krasnoyarsk Territory, Krasnoyarsk Region Science and Technology Support Fund to the research project № 17-16-24601.

DOI: 10.17516/1997-1370-0155.

Research area: culturology.

(C) Siberian Federal University. All rights reserved

* Corresponding author E-mail address: axu-ta@mail.ru; nevolkon@yandex.ru 


\section{Introduction}

Currently the traditional cultures of the indigenous peoples of the North are threatened with dissolution in the global culture. This applies to different components of culture - ethnic cuisine, traditional medicine, traditional types of economy management, etc. The article is devoted to the study of the current state of the decorative and applied art of the indigenous peoples, in particular - Dolgans, Selkups, Yessey Yakuts, etc. And not only it will analyzed the degree of preservation of the decorative and applied art of an individual people, but also it will attempt to identify promising formats for the development of decorative and applied art.

The article is written on the basis of the field research conducted in 2010-2016 in the places of compact settlement of the indigenous peoples in the Krasnoyarsk Territory - in Noska, Farkovo, Dudinka, Khatanga, Yessey, etc. In addition to the participant observation, the method of expert in-depth interview was also used. Experts were the representatives of the authorities specializing in the sphere of culture, as well as cultural workers of various ranks - from specialists and masters to directors of centres of folk art.

\section{Review of literature}

Decorative and applied art is to some extent an integral part of the culture of every indigenous people. The only difference is that some specific ethnoses develop a certain kind of activity that serves as a marker for their sovereignty against the background of a situation of multiculturalism (Krmpotich, Howard, Knight, 2016). The analysis of the most common types of decorative and applied art of individual indigenous peoples has been conducted by foreign scientists E.A. Asante, N.A. Opoku-Asare, R. Wemegah, C.K. Sahu, J. McGaw, D. Tzanidaki, F. Reynolds, G.N. Varavina.
Scientists analyze the decorative and applied art of the indigenous peoples from the perspective of its social purpose. Thus, the development of decorative and applied art, in particular the production of pottery ware among the indigenous peoples of Ghana (Sirigu), is considered by E.A. Asante, N.A. Opoku-Asare, R. Wemegah (Asante et al., 2015). There is a wide range of pottery ware that is manufactured both for household, religious and commercial purposes. Based on the analysis of raw materials, production technology and decorating features, the authors come to the conclusion that the art of making pottery ware has a positive impact on the quality of life of people, as well as on the art of Ghana in general. Traditional craftsmanship contributes to the fact that a craftsman receives recognition, endows himself with a special status among members of his community (Tzanidaki, Reynolds, 2011). C.K. Sahu studies the foundry of the indigenous peoples of India (Sahu, 2015). Products made by craftsmen are in great demand, both in the local and external markets. According to the author, this is due to their special religious purpose. Moreover, there is an expansion of the design solution for the manufacture of foundry products. In addition to the traditional images, door handles, boxes, hangers and other new products are being produced, which is evidence to the development of this craft.

A number of studies are devoted to certain types of decorative and applied art as a strategy of identifying oneself as a member of community. Thus, J. McGaw carries out the analysis of the art of making raincoats from the skin of possums (marsupial mammals living in Australia) and the specifics of its decoration (McGaw, 2014). The researcher notes a tendency of revival of this practice among the indigenous peoples of south-eastern Australia in the $21^{\text {st }}$ century. The author interprets the image in the form of symbols of knowledge about the country as a 
way of identifying oneself with the clan and the tribe. Pursuing traditional craft as a way of selfidentification of oneselfas a member of community is also analyzed by D. Tzanidaki, F. Reynolds (Tzanidaki, Reynolds, 2011). In the study of the ornamental art of the indigenous peoples of the Arctic Region (Evens and Evenks) G.N. Varavina notes that the ornament reflects the harmonious interconnection of a human and nature, expresses the characteristics of nomadic culture and serves as a protective amulet. The author points out the relevance of studying the traditional decorative culture of the indigenous small-numbered peoples of the North and Siberia. One of the perspectives of preserving the decorative and applied heritage of the autochthonous ethnic groups is the activity of employees of the Buryat Institute of Natural Sciences: through digitizing traditional ornaments of Mongolian people, it becomes possible to compose a particular encyclopedia of symbols that can be used to create new models based on the existing prototypes (Varavina, 2016).

Decorative and applied art of the indigenous peoples of the North and Siberia has been studied by such Russian scientists, as N.P. Koptseva, N.N. Pimenova, N.N. Seredkina, K.V. Reznikova, N.M. Libakova, V.Kh. Ivanova, E.V. Vorozhtsova, etc. Most of the research works belong to Siberian scholars in cultural studies who study decorative and applied art of the indigenous peoples as a factor in formation of a positive ethnic identity. In their article, N.P. Koptseva, N.N. Pimenova and N.N. Seredkina confirm the interconnection of the primordial religion and traditional art of the indigenous peoples of the North as factors of the formation of a positive allRussian cultural identity. It is noted that modern forms of festive and ritual culture and folk art have the opportunity to act as a real basis for the formation of a positive ethnic identity of the indigenous peoples of the North, as catalysts for the preservation of an ethnic group (Koptseva, Pimenova, Seredkina, 2013). The article by N.P. Koptseva， N.N. Nevol'ko, K.V. Reznikova analyzes the Evenki decorative and applied art as one of the mechanisms for the formation of a positive ethnic identity (Koptseva, Nevol'ko, Reznikova, 2013). N.M. Libakova analyzes the mechanisms for the formation of a positive ethnic and cultural identity among the indigenous smallnumbered peoples of the North, Siberia and the Far East on the basis of the analysis of art works of decorative and applied art made by craftsmen and representatives of the indigenous smallnumbered peoples of the Krasnoyarsk Territory. The author believes that the craftsmen - bone carvers living in Taymyr embody ethnic ideals, values, etalons in their art works, thus solving the problem of ethnic identity and self-identity among representatives of their ethnic group (Libakova, 2015).

As for other sources, it is possible to single out a research work by V.Kh. Ivanov who devoted a year to the system analysis of decorative and applied art of the peoples of the North-East of Russia. The researcher examines the interconnection of the decorative and applied art of the Evenkis, Evens, Yukaghirs, Chukchi and Koryaks in the northeast of Russia, describes the archetypes of typological models, identifies common features of ethnoses and determines the nature of this community (convergence, genetic ties and direct contacts) (Ivanov, 1999). E.V. Vorozhtsova makes a description of the decorative and applied art of the indigenous small-numbered peoples of the Far East, the Far North and the North-East of Siberia in the collection of the Sakhalin State Regional Art Museum (Vorozhtsova, 2008).

Several articles are devoted to the study of traditions of the northern peoples of the Caucasus by the example of the decorative and applied art (Drobysheva, 2004, 2012; Lesnevskaya, 2015). 
For example, weaving is a modern traditional kind of the decorative and applied art of the North Caucasus (Drobysheva, 2012).

Thus, the analysis of the existing scientific research works on the decorative and applied art of the indigenous peoples showed that this practice of culture in most cases remains in demand by the representatives of ethnic groups. The products of decorative and applied art serve not only commercial purposes, but also carry a function of a certain "construct" of ethnic identity. In addition to the existing studies, it is important to turn to the consideration of prospective formats for the development of decorative and applied art of certain indigenous peoples of the Krasnoyarsk Territory.

\section{The current state of decorative and applied art of the indigenous small-numbered peoples of the Krasnoyarsk Territory}

The current state of the decorative and applied art of the indigenous peoples of the region varies significantly. Some peoples have lost it almost completely, others, in their own words, are experiencing a revival of traditional culture in general, including decorative and applied art. The main directions of the northern decorative and applied art are the skin processing, sewing and decoration of clothes and shoes, bone carving. The main attention will be given to these directions.

\section{Selkup decorative and applied art}

The Selkups in the village of Farkovo (Turukhansk District of the Krasnoyarsk Territory), which is the place of their compact settlement, do not wear national clothes either in winter or in summer; but still keep memory about it, because the parents of the older generation who lived in chums constantly wore it. So, according to the Selkup stories, the national clothes are very beautiful, they were made of reindeer hides of soft finishing and decorated with fur and beads. Clothes were two-layered: the bottom layer skins of deer or arctic foxes, external layer - a material embroidered with beads. At the times when there were no beads or they were very hard to get, clothes were decorated with pieces of fur of different colours. According to the representatives of the ethnos, traditional Selkup clothes include deerskin parkas, and the parkas were so warm that if wrapped in such clothes one could sleep in the taiga right on the snow. Speaking of national shoes, the Selkups wore bokari, mukluks and boots. Bokari, according to local people, are a kind of fur stockings. Most often shoes were made from reindeer skin that, when properly processed, did not fade with time. The Selkups made boots from pelts of burbots; processed in a special way, they did not get frayed.

There is no revival of the Selkup decorative and applied art in the Krasnoyarsk Territory, the tradition broke off completely. But in a local school in Farkovo a handicraft teacher organized training of children in the craft of dressing heads of large pikes just like the heads of beasts - hunting trophies (Fig. 1). He himself mastered this craft when serving in the army, and when he returned back home he began to train children. On the one hand, this activity has no connection with the traditional Selkup decorative and applied art; on the other hand, hunting and fishing are the original forms of the Selkup economy management; therefore, making pike heads is quite naturally perceived by the local population and is popular among schoolchildren.

\section{Decorative and Applied Art of the Yessey Yakuts \\ The main types of decorative and applied art of the Yessey Yakuts (mainly live in the settlement of Yessey of the Evenki Municipal District of the Krasnoyarsk Territory) are sewing}




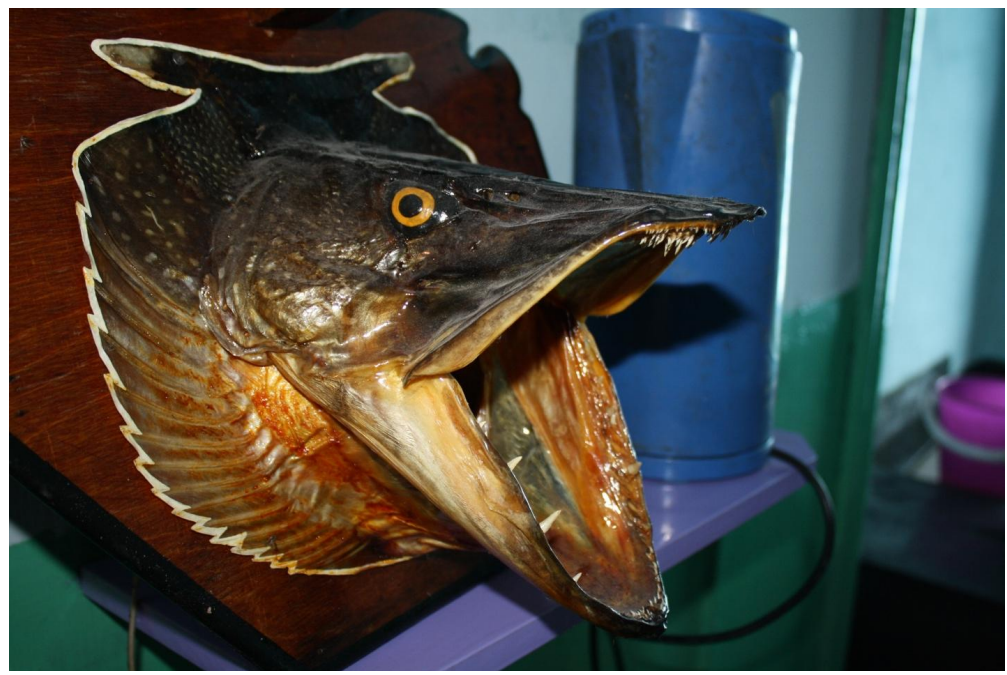

Fig. 1. Dressed pike head

of traditional clothes, shoes and beadwork. Traditional clothes, according to the Yessey Yakuts, are mostly preserved in those settlements where there are hunters, where reindeer breeding is developed. For the most part, traditional men's clothing is preserved, as it is men who are engaged in fishing and hunting in the taiga. Old men also have traditional clothes, but they no longer wear them. Traditional clothes are parkas with fur inside covered with a deer hide without high pile. National Yakut clothes were made from reindeer skins. Clothes were very practical, well-dressed skins could be stretched enough. The clothes were cut to fit tightly and keep the warmth well. There were no buttons, so they sewed suede eyelets. Hats were with hoods and were sewn from three parts. Along seams Yakut clothes could be decorated with strips of red cloth. Fells of the hats were covered with fur of wolverine, arctic fox or lynx. Mittens were sewed from the deer skin. Bokari sewn from the deer skin were decorated with fur mosaic or beaded patterns. Summer shoes were made from suede. Such shoes are still being sewn, children from the dance collective wear them while performing. Young people do not wear traditional clothes at all, they prefer purchased clothes.
The fur mosaic of the Yessey Yakuts differs from the Nenets one in that the insets of different colours are not separated by pieces of cloth, which gives the impression that the fur pattern is not artificially created, as if the deer skin was originally with spots of this shape (Fig. 2). Bead patterns combine both traditional Yakut floral motifs and geometric patterns of peoples inhabiting the territory of the present Krasnoyarsk Territory before arrival of the Yakuts.

Modern workshops specialize in making short fur boots with padding from the hooves of deer for hunters and reindeer herders. Before, there was a fur workshop in Yessey supplying traditional clothes to all nearby settlements, even to Olenek (Yakutia). In the 2000's, the workshop was revived. The head of the workshop bought equipment and raw materials for making shoes. In the workshop, there are 3-5 local women, as a rule, from socially vulnerable groups of population who are provided with employment and the piece-work payment for labour. The workshop is focused not only on sewing warm and comfortable clothes, but also on decorating it with traditional motifs to preserve identity (Fig. 3). The head of the 


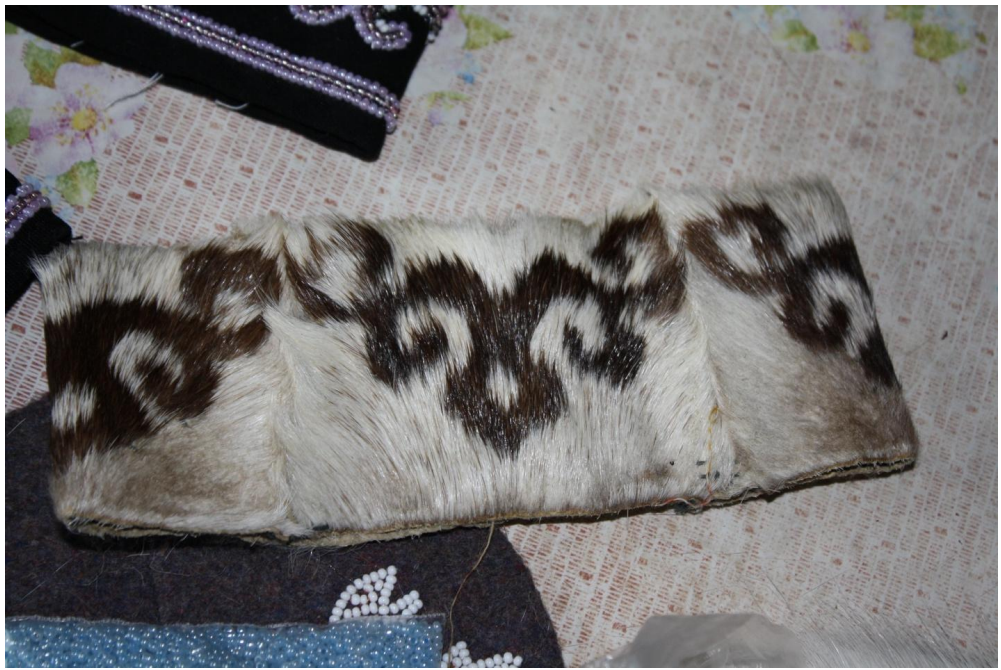

Fig. 2. Fur mosaic
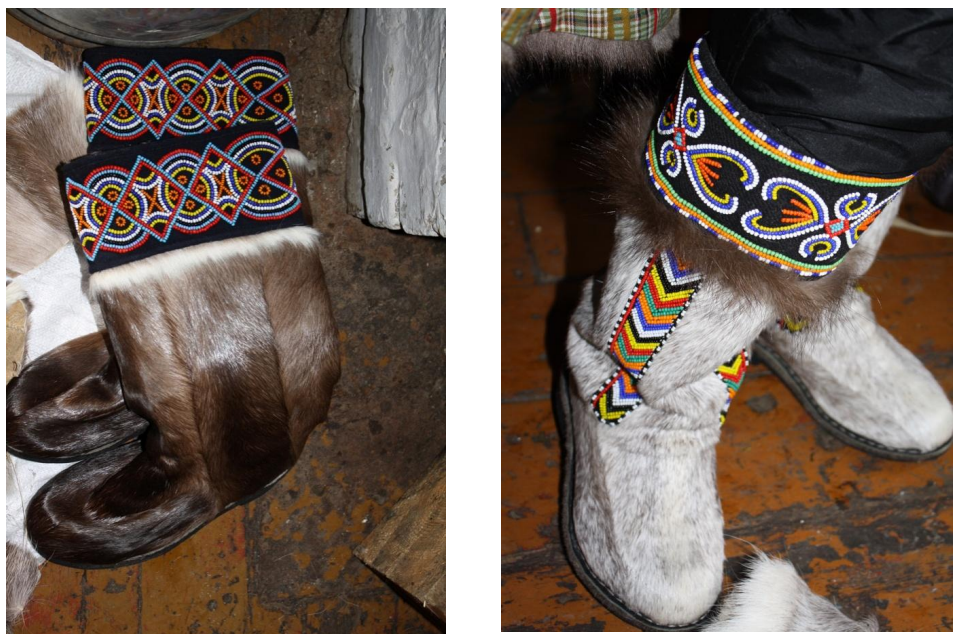

Fig. 3. Fur boots with traditional beadwork

enterprise says that she has obtained her skill from her mother and grandmother who still continue to help her work.

Processing of skins has always required a lot of work before. They are treated with various scrapers, they are dried and re-wet. For wetting the skin, the craftsmen use rotten wood that is powdered and diluted in water. The same tools are used in processing hides as centuries ago (Fig. 4). When sewing clothes the masters use dried deer veins instead of threads. The soles are made both from artificial materials and from natural ones, in particular, a sole for one pair of male boots requires about 40 small (about 3 pcs for $7 \mathrm{~cm}$ ) pieces of well-made feathers from deer hooves, the wool of such feathers practically does not get frayed off (Fig. 5). For tailoring clothes skins of deer, wolverines, mountain rams and wolves are used.

The Yessey school teaches decorative and applied art, in particular - beadwork. Not only children's, but also adult household items, for example, bags are decorated with beans (Fig. 6). The most common pattern is a horn of a deer that 


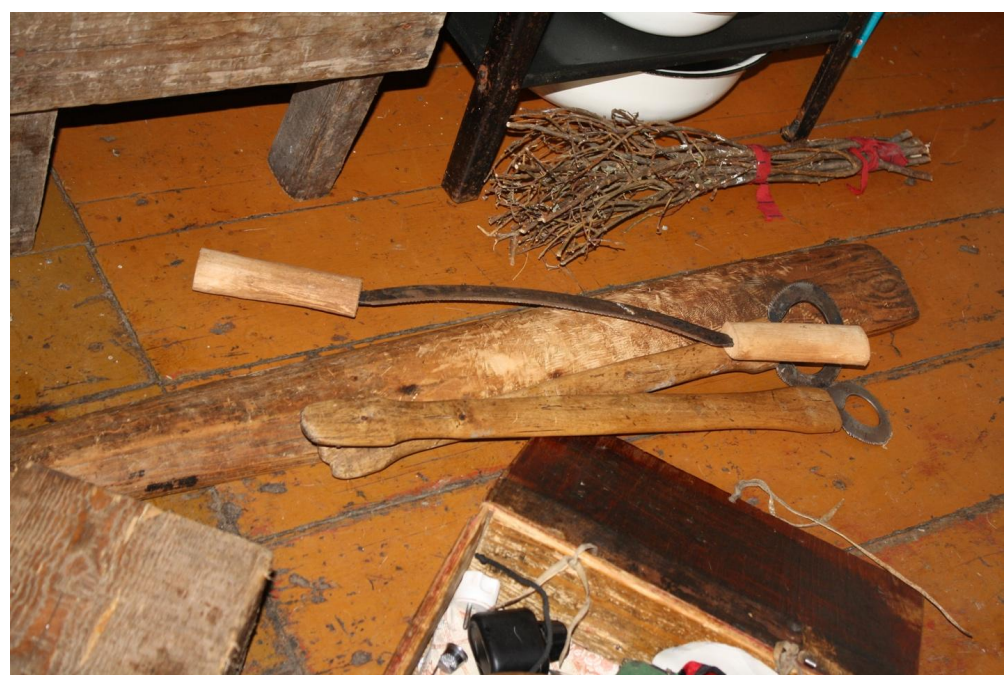

Fig. 4. Tools for dressing skins

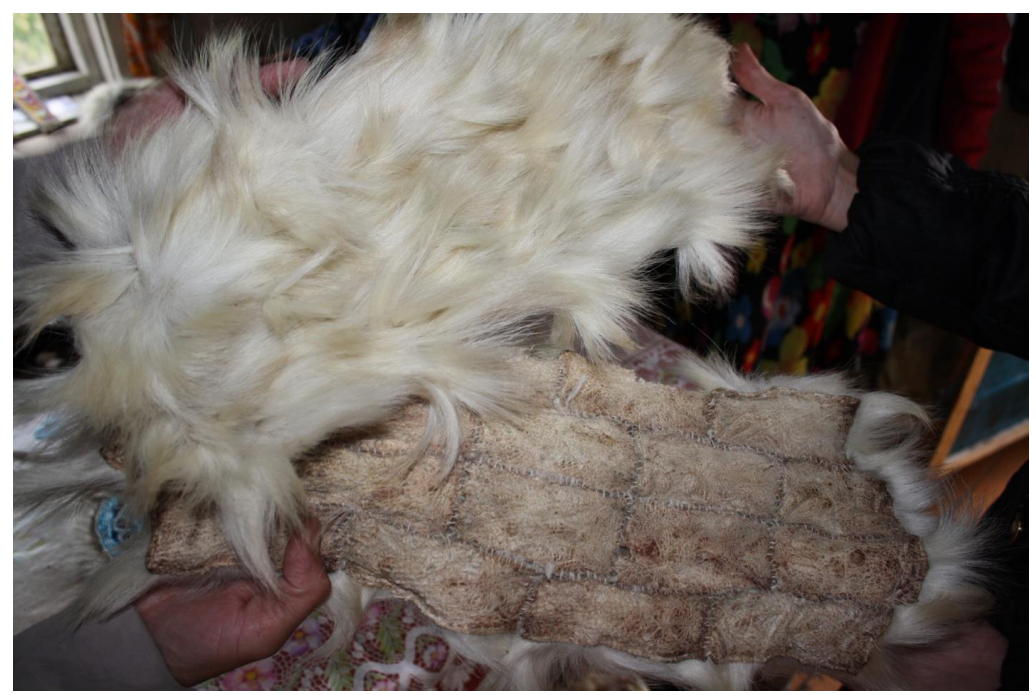

Fig. 5. A sole of boots made of feathers from deer hooves

inhabits the Putorana (Fig. 7). It is a spiral-horned deer, and to see it is a great luck. Also among the popular patterns there are the images of waves of the Yessey Lake and the mountain towering above it.

\section{Nenets decorative and applied art}

The main features of the Nenets decorative and applied art are sewing of traditional clothes, shoes and beadwork. Clothing and footwear are actively used in everyday life, not only on holidays.
But this applies only to winter clothing (Fig. 8). In the summer, the Nenets prefer clothes "from the mainland" - clothing of mass production that is common throughout the country. Suits made of durable fabric - special costumes protecting from insects are especially popular in the summer. The national Nenets clothing is a deerskin jumper (male) and parka (female). Even the Russians living in the settlement of Nosok (Nenets settlement, Taymyrsky Municipal District of the Krasnoyarsk Territory) say that there is no 


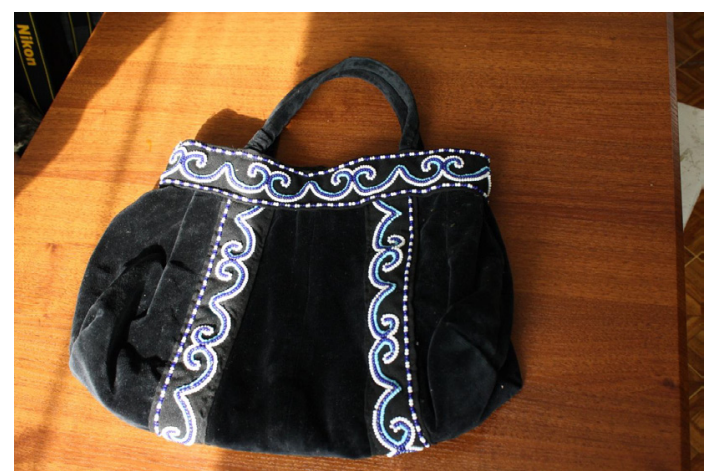

Fig. 6. A bag with traditional beadwork

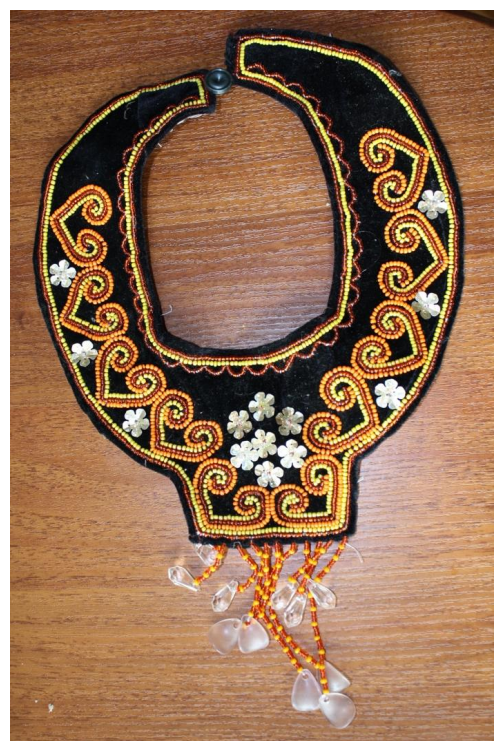

Fig. 7. Traditional pattern - horns of a spiral-horned deer

warmer clothing; they also say that one cannot live in the tundra without Nenets clothes.

Nenets clothing is two-sided: with fur inside and outside. Mittens are attached to the clothes, which is very convenient, according to local residents. A jumper is sewed without fasteners, a parka is unfastened (initially it was designed for the possibility to feed a child); fastening is made of suede eyelets. The jumper includes a hood, and the parka is sewn without a hood and is trimmed with fur. On top of the jumper, people often wear a special thick cloth cover ("outer covering"), and therefore the upper part of the parka may consist of an inner fur layer and an outer cloth one. The local people are sewing parkas or jumpers for children from the very early days with the only difference from the adult variants that in the first year of life mittens are sewn without separating a thumb.

A material used for the mittens is a deer leg skin (kamus), for parkas and jumpers - deer skins, welt - arctic fox fur. Clothes are sewn with the help of dried and specially processed deer sinews that replace threads, if they are not enough, a nylon thread is used. In general, it takes a week to sew one jumper or a park. Processing kamus is a longer and more complex process: after the initial dressing kamus is dried, so that the inner side of hide dies away; then kamuses are soaked with water to make the inner side of hide soft; through time they are treated with a scraper. After the secondary dressing kamus is dried again, processed again and sprinkled with fish oil. After the fat dries out there is another dressing of kamus. Kamus differs depending on the harvest season: in autumn it is shaggier, while in winter the pile is longer and thicker.

The widespread Nenets footwear is fur boots, less often - bokari. Fur boots are sewn by local craftsmen and decorated with ornaments made of reindeer skins, and soles are made in Dudinka. An innovation in the manufacture of footwear is the use of artificial fur for sewing the inner layer of shoes: since the artificial fur does not fall, the socks remain clean, while using natural fur for the inner layer of shoes; problems arise with the falling pile. Nenets outerwear and footwear are decorated with coloured cloth and ornament made from black, white, brown and gray fur; between the strips of fur a cloth is sewed in, and most often it is red (Fig. 9). The ornament is sewn mainly with the help of sinews. The symbolism of colour and ornament design is now virtually lost, so when choosing combinations, the craftsmen are guided solely by beauty. 
The local inhabitants of Noska called a purse-tuch' a national female attribute (Fig. 10). There is a belief that if a girl did not sew her own handbag as a child, she would not marry, so it is considered that from the age of 10 girls should start sewing tuch's. Handbags are sewn from a well-made deer skin, and there are sections for thimble and needles. The handbag is decorated with all sorts of decorations: buttons, badges, pendants, beads and even empty cartridge cases.

\section{Nganasan decorative and applied art}

The traditional art of the Nganasans is tailoring. Unlike the clothes of the Yessey Yakuts or Dolgans embroidered with colourful beads or the mosaic clothes of the Nenets using coloured cloth, the Nganasans used only three colours white, black and red (Fig. 11). When there were no artificial colouring agents, they used natural paints (coal, stones, trees, dust). Each master had a stone, and paint was rubbed on it. Saliva was used as a binder; compared with water its viscosity is greater. The Nganasans sewed clothes from deer skin and rovduga (reindeer hide). White rovduga was taken from the belly of a deer, it was cut, and in the spring it was weathered on the street to become even whiter.

Parkas were decorated with various ornaments, including "teeth", "hare ears", etc. Selection of an ornament was first determined by a social position of the owner of clothes. By looking at the parka, just like by passport, it was possible to understand the owner's marital status, his age, how many children he had, what kind of household he owned, what he did. The skin was cut in ornamental strips with the help of a metallic (often brass) arc-shaped decoration -a craftsman painted strips on the skin using its edge.

Clothes were trimmed with dog's fur. White dogs were specially held to be used later on. Such a dog was very expensive. The Nganasans consider wolves, bears, wolverines to be sacred

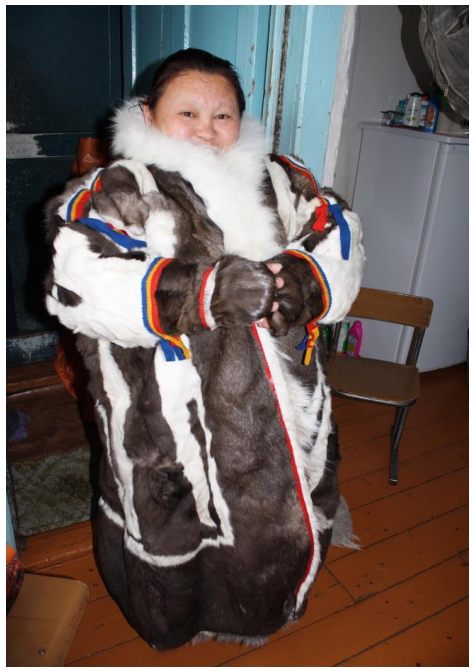

Fig. 8. A Nenets woman in traditional clothes

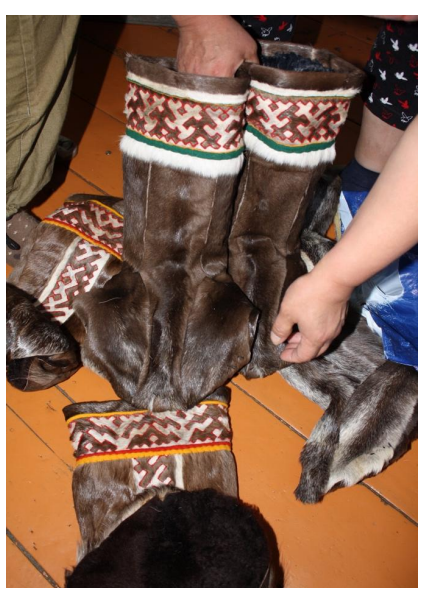

Fig. 9. Fur boots with traditional ornament

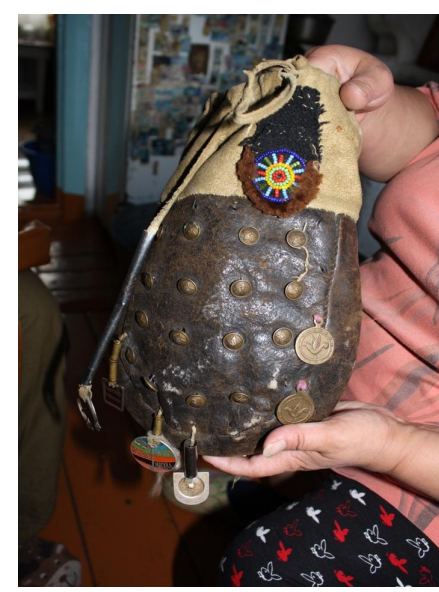

Fig. 10. Traditional female Nenets handbag 


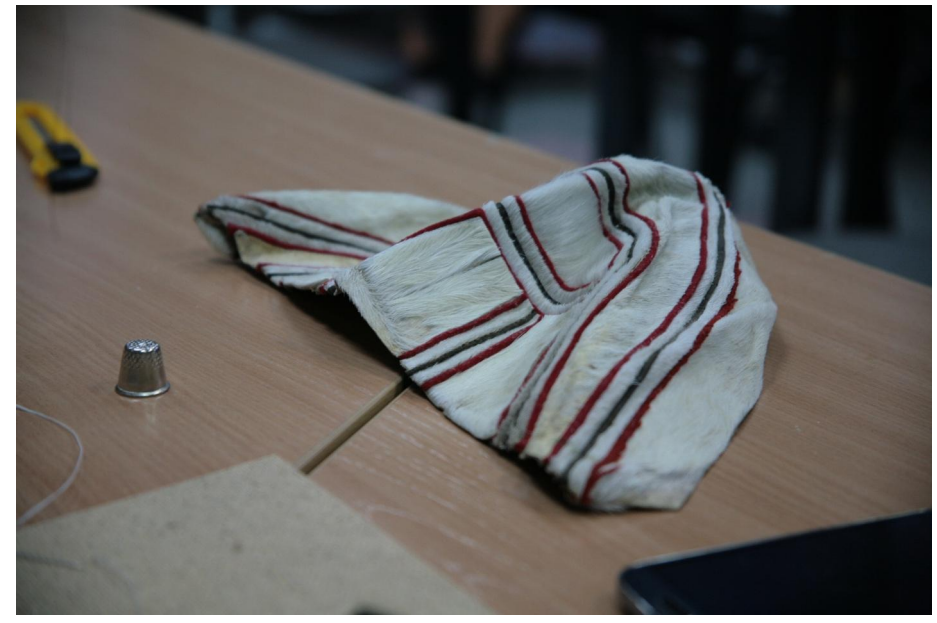

Fig. 11. A detail of the traditional Nganasan clothing

animals, and one cannot sew clothes from them. The Nenets, on the contrary, tried not to use a dog, they believed that only those Nenets who had few deer used a dog; if you begin to trim clothes with a dog, your well-being decreases.

A male parka was made closed. A female parka was open, wrapped so that a mother could feed a child. Holiday parkas eventually got worn out and got to be used every day. Not only Nganasan clothing differs from other traditional clothes, but also shoes that were sewn cylindrical. It was done this way in order not to fall into the snow.
The authorities are making attempts for the centralized preservation of the Nganasan decorative and applied art - clubs and individual masters work under the municipal cultural institutions. Thus, the Nganasan club functions at the City Centre of Folk Art in Dudinka, on the basis of which master classes are held to create traditional Nganasan patterns, to dress skins (Fig. 12). The Nganasan master works in Dudinka and at the House of Folk Art. A sewer of Nganasan clothing works at the Centre of Folk Art in Khatanga - Varvara N. Popova who received the title "Masters - the golden

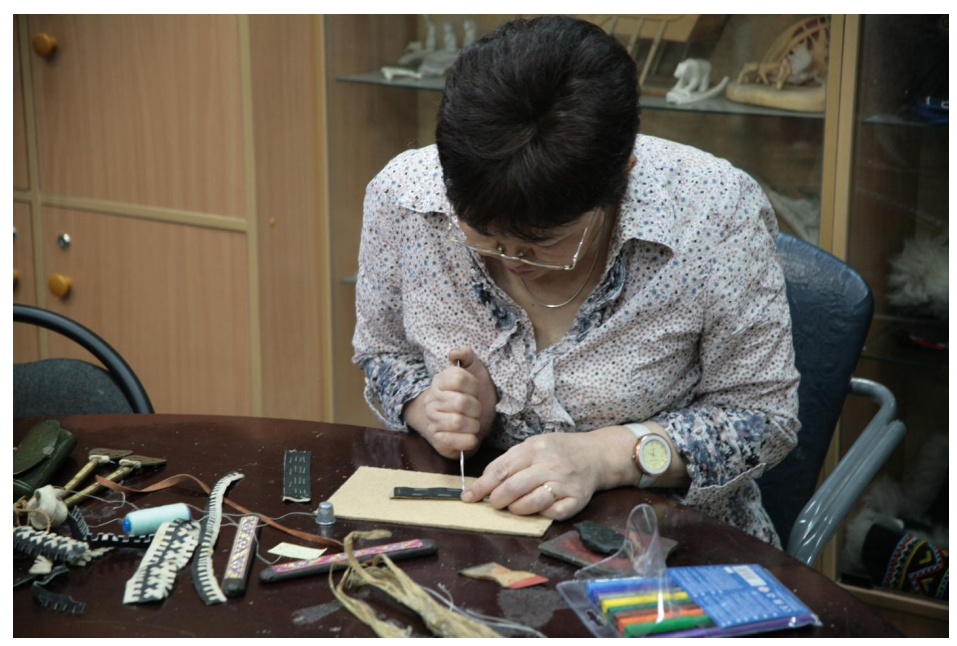

Fig. 12. Master-class on traditional Nganasan patterns 
hands of Krasnoyarsk" in competition held in Krasnoyarsk in 2013.

\section{Dolgan Decorative and Applied Art}

At present, the preserved decorative and applied art of the Dolgans is sewing of traditional clothes and shoes, as well as bone-carving. Traditional Dolgan clothing is preserved in everyday life, mainly in remote villages, although people gradually break from this tradition, but they do not throw away or sell parkas, but they try to preserve them. On holidays (Reindeer herders day, days of settlements, etc.), almost all the population comes out in traditional clothes. There are parkas that are specially sewn for children. Those who go fishing or hunting in winter, regardless of their ethnicity, wear winter jackets, Dolgan hats that are warmer than clothes and shoes from stores.

As the Dolgans note, their ethnos has formed from several peoples - the Yakuts, the Evenks, and Russian peasants living in the tundra. And the latter were the ones who created the look of the traditional Dolgan parka; if you look closely at it, it is a Russian female small armiak. It is made according to the canons of the Russian national costume, but with the northern ornaments beads, braids, fur of different animals.

Traditionally, the Dolgans processed skins using the liver. According to various evidences, it was either boiled or gone through a meat grinder, coating the skin to remove the inner side of hide; or they chewed cooked liver and spit it out coating the skin with the resulting composition of the liver and saliva. Currently, chemicals are used for processing of skins, but the Dolgans believe that chemically treated skins do not keep warmth.

The Dolgans from Khatanga lament that knowledge of how to sew clothes and shoes is getting lost. On holidays in the cattle camps one can see a lot of stylized clothes. And there are not that many masters left who can make real traditional clothes in accordance with the canon of the tundra, with selection of an ornament and colour scale. Traditionally, the Dolgans decorate clothes with beads, but now the symbols of ornaments are not preserved. The patterns are chosen by craftsmen according to their own taste. The Dolgans use beads of all colors of the rainbow, the brighter - the better.

The skill of sewing traditional footwear is also getting lost. As the Dolgans say, you cannot buy a winter jacket without knowing the master, because they are very expensive and, most likely, low-quality. The lack of quality is associated with the use of non-traditional materials, for example, caprone threads that tear the reindeer skin. Traditionally, the clothes were sewed with veins: when shoes got wet, veins became wet as well and stretched out; when the shoes dried out, the veins shrunk back to normal.

The Dolgans say that a significant layer of traditional decorative and applied art has been lost. According to the memoirs of the representatives of the ethnos, long ago, festival clothes, both male and female, were decorated very beautifully. At the same time, there were practically no pectorals, only metal hanging ornaments were attached to a belt from the back. In the old days, the Dolgans used decorated sledges during the holidays. They were made from the mammoth tusk found in the tundra.

A great damage to the decorative and applied art was done in the 1990's, when the parkas were thrown out, not knowing their value. In the late 1990's many tourists visited the North Pole through Khatanga; they showed interest in traditional clothes and mainly bought hats.

The Dolgans believe that the Vocational Training Facility, where traditional art was studied, helped to preserve at least part of the traditional decorative and applied art in the $20^{\text {th }}$ century. At present, the traditions of the Vocational Training Facilities at schools are 
continued by the fact that in some villages of Khatanga, in schools and kindergartens, there are study groups of decorative and applied art, where children are taught to bead souvenirs and belts.

A natural tradition to pass the mastery of decorative and applied art inside the family from the eldest to the juniors is getting lost as well. Children are taught to bead in schools, and to carve bones - in vocational schools. Years ago children were taught how to bead, sew the clothes and carve bones at home, and often they just watched their parents and mirrored them. In some families, special attention was paid to the teaching of decorative and applied art. Mothers did dolls for their daughters, so that they could learn to embroider beads for clothes of small sizes first.

At present, the Dolgans record the growth of ethnic self-awareness; therefore women try to keep those parkas that they have inherited, especially the old parkas. The Dolgans say that national clothes, especially in large cities, began to revive, particularly among the intelligentsia. So, instead of fur coats they buy parkas supplementing them with shirts, beaded bags and traditional hats.

The authorities of settlements are also actively helping to preserve the Dolgan culture. For example, a Dolgan family club functions at the City Center of Folk Art in Dudinka, and in Potapovo an embroidery workshop is operating. The family form of work of clubs is effective, because different generations of the Dolgans are involved. Also a Dolgan craftswoman works in the House of Folk Art in Dudinka. Sewing and fur studios, training and production workshops for bone carving have been working in the House of Folk Art since 1995.

The Taymyr Centre of Folk Art received a grant from the Norilsk Nickel company in the "Our City" nomination in the amount of one million roubles for the construction of an ethno- cultural complex, including a large courtyard area and land improvement. It was supposed that this would be a national platform where events would be held, an ethnic camp and ethnic-style gazebos would be unfold. The platform will be decorated with carved idols, benches in the form of sledges, swings in the form of deer.

An interesting way to preserve the traditional decorative and applied art of the Dolgans carried out by specialists of the House of Folk Art in Dudinka is the creative research expeditions. In the course of them, the participants collect various materials: folklore, clothing and ornamental motifs. The main tasks of expeditions are to define the state of decorative and applied art in settlements, to create a methodological material and to record it photographically.

With the help of their traditional culture, including decorative and applied art, the Dolgans are trying to break through a negative attitude to themselves from the non-indigenous population. For example, for this purpose the "Big Argish" event is held annually in Norilsk, where the organizers exhibit chums and traditional treats. As the director of the Taymyr Centre for Folk Art notes, "people in Norilsk wait for this holiday every year. People devoted their lives to breaking these stereotypes by their example. Family clubs have played an important role for this. It is people who light others around them".

Employees of the House of Folk Art in Dudinka associate the further development of traditional culture, including decorative and applied art, with the creation of a cultural ethnopark in the territory of Taymyr, suggesting that it will not only be a site of the tourist route, but also an educational base.

The local population tries to support and restore the traditional culture in an integrated manner, rather than decorative and applied art separately. Thus, the Taymyr Education Department helps to establish language classes 
in kindergartens, at the same time children are engaged in sewing traditional costumes, learning songs and tales in Dolgan. Employees of the House of Folk Art in Dudinka also work in a complex manner. According to the chief curator V.I. Batagay, "I saw Centres of Folk Arts in different regions and subjects of the Russian Federation. They are directed either at folklore or at the decorative and applied art. Our centre is focused, firstly, on folklore (foundation), then there is decorative and applied art and then children's studios and club organizations (workshops of bone carvers, modern and traditional costumes, old singing)."

In Khatanga, the Dolgan decorative and applied art is also preserved in a centralized way, for this purpose the Centre for Folk Art was established in 1995. It employs bone-carvers (Fig. 13), sewers of traditional clothing (Fig. 14). Also in the Centre of Folk Art of Khatanga there is a portfolio for each master. Periodically, new masters appear in the file cabinet. For example, some students from Norilsk come to Khatanga and participate in exhibitions; if participation becomes regular, then they are registered as masters in a card file. One of the activities of the Centre is participation in exhibitions and competitions held in Krasnoyarsk, Omsk, Moscow and Finland. The Centre also cooperates with kindergartens and schools. Traditionally, in March, the Centre conducts lessons on national culture, where anyone can get acquainted with bone carvers, with the features of making clothes. The cultural and educational program is adapted to the age of the participants. The Centre also conducts master-classes on beadwork, fur processing and carving. Masters of the Centre make traditional toys for kindergartens. For example, in 2014, for the "Snowflake" kindergarten the Centre made a game from the bones of a deer leg embroidered with beads. The game is a chum, the poles of which can be assembled and disassembled with small toys doing a circle dance-heyro.

In order to preserve decorative and applied art in some settlements, for example, in Khatanga, the local population hold competitions of national costumes, a contest of dolls in national costumes called "The Magic Needle". In 2012, 100 people took part in the "Magic Needle". And although the traditional Dolgan doll is ragged, the competition presented clothes that were put on plastic dolls. In Dudinka, they hold a contest of decorative and applied art called "Northern Souvenir", where

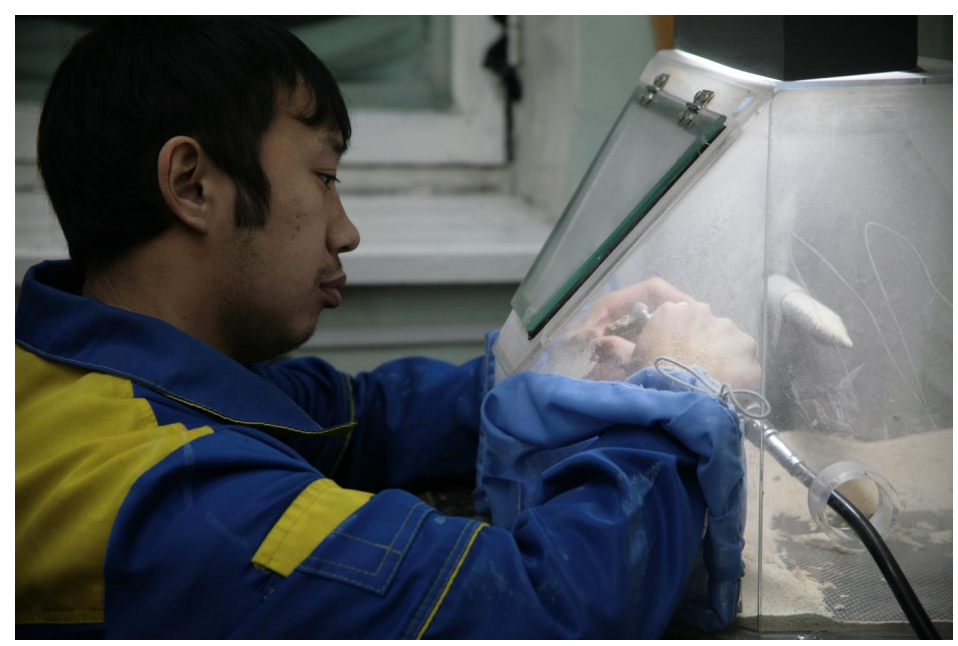

Fig. 13. Bone carver at work 


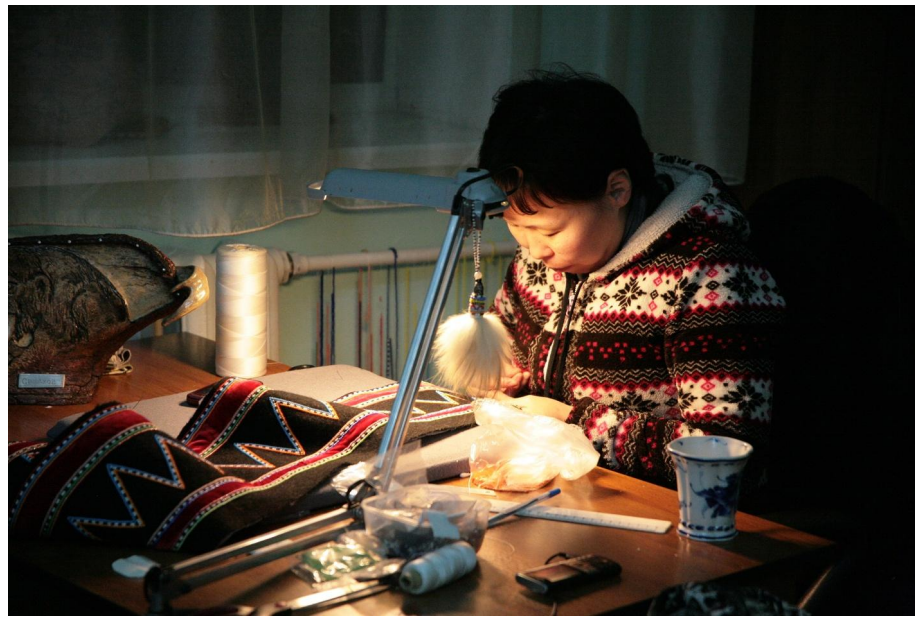

Fig. 14. A craftswoman making a Dolgan costume

the head of the city rewards the winners, which is considered very honourable.

The Centre of Folk Art of Khatanga faces a number of problems, one of which is personnel: in Khatanga there are a lot of young people who graduated from Norilsk College, Taymyrsky College. But there are not enough working places, especially in settlements. With the absence of working places, masters work on a private basis; they sell their works, and do not store them. The premises of the Centre of Folk Art are also not enough.
Another form of preservation of decorative and applied art is the private entrepreneurship. A workshop called "Mukustur" that was established by a Dolgan woman A.I. Porotova (Dudinka) is a good example (Fig. 15). A.I. Porotova participates in grant programs of different levels - from municipal to federal. Under the grant she was also awarded premises, in which a workshop and a store are located. On the advice of the Governor of Taimyr, Budargin, A.I. Porotova began to travel with a chum for holidays in Norilsk. She says that she participates in all the grants: "Why should I

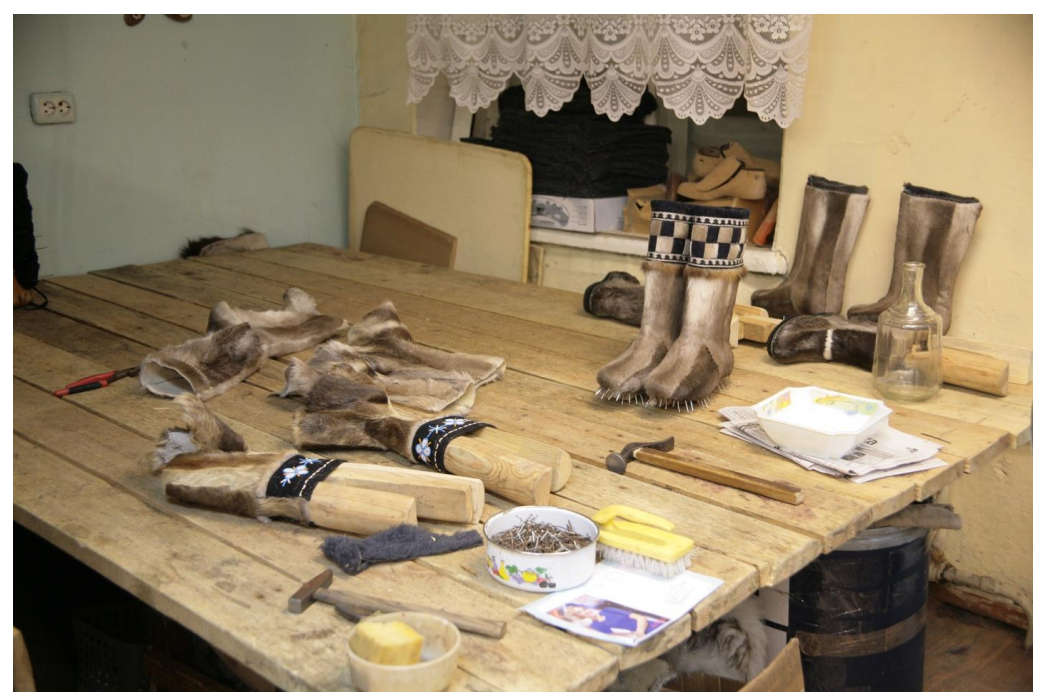

Fig. 15. "Mukustur" workshop 
miss this if the state gives an opportunity? People are shy, afraid to apply, because they can lose. I strengthened the material and technical side of life thanks to grants". A.I. Porotova says that everyone can live like her, if they stop grumbling and start acting - sewing, selling, going to exhibitions, etc. She associates the improvement of the decorative and applied art in the future with the organization of sales markets, including those that depend on the development of tourism in the North. A.I. Porotova believes that the Dolgans always used things that the merchants brought for tailoring and decorating clothes. Continuing this tradition, she uses Sergiev Posad shawls in sewing vests, claiming that "since the merchants have been transporting shawls for centuries and have been exchanging goods, I believe that a Sergiev Posad shawl is also part of my culture".

Perspective formats for the development of decorative and applied art

On the basis of the above material, several main prospective formats for the development of decorative and applied art, both those that are already used by the indigenous small-numbered peoples and those that could be effectively used in the future, can be identified.

\section{Organization of training classes on} decorative and applied art for children in the form of school lessons (crafts) or clubs in institutions of additional education. Such a format for the development of decorative and applied art is used by the Dolgans, the Yessey Yakuts and other peoples of the region, and it has proved itself to be positive: often children who visit such clubs continue to practice decorative and applied art in specialized technical schools, graduating from which they become masters and work in cultural institutions. But even if the skills in decorative and applied art do not serve as the basis for the future profession, they will remain the skills that will allow people to wear through the day or make their clothes more beautiful.

Organization of master classes on decorative and applied art for people of different ages, for example, within the framework of family ethnic clubs. Several such clubs operate in Dudinka (Nenets, Dolgans, Nganasans); involvement in such clubs allows not only preserving and developing decorative and applied art, but also contributes to the improvement of relations in a family and in a society as a whole.

\section{Organization of private production} units for sewing traditional clothes. Sewing workshops operate in Dudinka ("Mukustur"), in Yessey (fur workshop). They are aimed at both local residents who use traditional clothes and shoes in everyday life and visitors who want to buy ethnic costumes as souvenirs.

Carrying out ethnic holidays and competitions among works of decorative and applied art. This format is widely popular in the North of the region. Not only the viewers and participants demonstrate traditional clothes, cook traditional food, but also compete in the native skills - repairing and setting up nets, removing reindeer skins, controlling a reindeer harness, etc.

Creation of ethno-parks. The representatives of the indigenous peoples often mention this direction as a perspective for the development of decorative and applied art. But it cannot be implemented until the tourism infrastructure in the northern territories of the region is properly organized, because the ethnopark should exist at the expense of visitors.

Expedition work. This format of preservation and development of decorative and 
applied art functions in Dudinka. Expeditions make it possible to discover unique samples of decorative and applied art in remote parts of the region. The collected photographic material serves both for the reconstruction of traditional artefacts and for conducting master classes.

\section{Combination of traditions and modernity} in the technology of decorative and applied art.

This format of preservation and development of decorative and applied art is in demand by virtually all the indigenous peoples of the region. But such activities are carried out by trial and error, so some technological moves prove to be both successful (using artificial fur as the inner layer of footwear, using Sergiev Posad shawls in sewing traditional clothing) and unsuccessful (using caprone threads for sewing clothes and shoes from skins, processing skins by chemical means).

\section{Exchange of production experience} between masters of decorative and applied artthis format is important because of the availability of both successful and unsuccessful experiments of combining traditions and modernity in the production technology of decorative and applied art. Exchange of experience is necessary for a wider distribution of effective findings and for reducing (or eliminating) the typical mistakes made by different masters.

\section{Synthetical character in preserving and} developing culture of the indigenous peoples the work on the preservation and development of several directions (ideally, the whole set) of traditional indigenous culture is seen as more effective. Complexity is characteristic of expeditions conducted by specialists from Dudinka who collect not only samples of decorative and applied art, but also folklore works, and later they apply them in their work - in master classes, in performances of ethnic ensembles. This complexity can be implemented at the level of individual classes for children or at the level of family clubs - in parallel with the practice of decorative and applied art the participants can collectively perform songs or discuss their lives in their native language.

\section{Making decorative and applied art} utilitarian. In several interviews the experts noted that the indigenous people tend to use utilitarian attitude to art; it did not exist by itself, the things used in everyday life were decorated. Probably, the return of utility, for example, to bone-carving skill, will create new opportunities for the development in this area of decorative and applied art. Bone carving art is developed in a lesser degree than sewing clothes that continues to persist in everyday life. Earlier, bone carvers decorated deer harnesses; nowadays, the works made in bone-carving workshops are kept in museums and sold as souvenirs. We should try to determine how the works of northern masters could be used in everyday life; probably it could be knife handles, lamp shades for lamps, badges, etc. Traditional embroidery with beads can be used to decorate not only clothes and shoes, but for example, to decorate laptop and tablets cases that are widely in demand "on the mainland".

\section{Creation of new directions of decorative} and applied art that do not contradict traditional culture. In fact, this is the job of the Selkup in Farkovo who teaches crafts at a local school, and who have mastered the skill of making stuffed animals from the heads of large pikes and teaches children. Fishery is now a traditional type of the Selkup economy and one of the main types of their activities; therefore, the production of such works of decorative and applied art is positively met by the ethnos. One of the promising new directions may be the creation of prints for fabrics based on 
traditional patterns of the indigenous peoples. Clothes made from such fabrics can be sewn not only for northerners, but also for residents of the central and southern regions of the region and beyond.

\section{Participation in grant programs of different} levels. The importance of this direction for the preservation and development of decorative and applied art was noticed more in Taimyr. It is interesting that the grant support is received both by private enterprises specializing in decorative and applied art (for example, "Mukustur") and municipal cultural institutions (the House of Folk Art in Dudinka).

\section{Conclusion}

The contemporary state of the decorative and applied art of the indigenous peoples of the Krasnoyarsk Territory, in particular the Selkups, the Yessey Yakuts, the Nenets, the Nganasans, the Dolgans, is characterized from the standpoint of the coexistence of traditional activities of this practice and new formats for its development. Traditional activities of the decorative and applied art are associated with sewing clothes, shoes, beading and bone carving. In most cases, the products of the traditional decorative and applied art are not used by representatives of ethnic groups in their daily lives, thus acquiring a status of some artefacts of traditional ethnic culture. An exception is the communities carrying out traditional economic activities and living away from urban centres. For them, the products of the traditional decorative and applied art form the basis of their daily life.

New formats of the decorative and applied art (organization of classes on the decorative and applied art for children, master classes in the decorative and applied art for people of different ages, private production of traditional clothing, organization of ethnic holidays and competitions of works of the decorative and applied art, creating ethno parks, expeditionary work, combination of traditions and modernity in the technology of the decorative and applied art, etc.) are aimed at the revival, preservation and development of the traditional practice of this sphere of culture in the life of ethnic groups. This direction, in turn, allows forming and supporting the growth of ethnic self-awareness of representatives of the indigenous peoples.

\section{References}

Amosov, A.E., Bakhova, N.A., Bokova, V.I. (2012). Korennye malochislennye narody Severa $i$ Sibiri v usloviiah global'nykh transformatsii (na materiale Krasnoiarskogo kraia). T.1. Konceptual'nye i metodologicheskie osnovy issledovaniia. Etnokul'turnaia dinamika korennykh malochislennykh narodov Krasnoiarskogo kraia [Indigenous minorities of the North and Siberia under conditions of global transformations (based on the material of the Krasnoyarsk Territory). Volume 1. Conceptual and methodological bases of research. Ethno-cultural dynamics of the indigenous small-numbered peoples of the Krasnoyarsk Territory]. Krasnojarsk, SFU.

Asante, E.A., Opoku-Asare, N.A., Wemegah, R. (2015). Indigenous pottery at Sirigu: Dialogue on materials, methods and socio-cultural significance. In Craft Research, 6 (1), 31-56.

Avdeeva, Iu.N., Libakova, N.M. (2015). Mezhdunarodnye praktiki sotsiokul'turnogo proektirovaniia po otnosheniiu k korennym malochislennym narodam Severa, Sibiri i Dal'nego Vostoka [International practices of socio-cultural design in relation to indigenous small-numbered peoples of the North, Siberia and the Far East]. In Sotsiodinamika [Sociodynamics], 10, 10-38. DOI: 10.7256/2409-7144.2015.10.1643. 
Bobrik. I.E., Vdovin, A.S., Makarov, N.P. (2017). Sud'ba severnykh tserkovnykh arkhivov Eniseiskoi gubernii v 1920-1921 gg. [The history of the northern church archives of the Yenisei province in 1920-1921]. In Severnye arkhivy i ekspeditsii [Northern archives and expeditions], 1 (2), $6-22$.

Bukova, M.I. (2016). Osobennosti etnokul'turnogo samosoznaniia etnicheskoi gruppy chulymtsev, kompaktno prozhivaiushchikh na territorii derevni Pasechnoe Tiukhtetskogo raiona Krasnoiarskogo kraia (Tsentral'naia Sibir'). In Sotsiodinamika [Sociodynamics], 4, 41-51. DOI: 10.7256/24097144.2016.4.18414.

Bukova, M.I. (2017). Severoved i antropolog Vladimir Germanovich Tan-Bogoraz: "vserossiiskii khudozhestvennyi reporter" [Researcher of the North and anthropologist Vladimir Germanovich TanBogoraz: "All-Russian art reporter"]. In Sibirskii antropologicheskii zhurnal [Siberian anthropological journal], 1 (1), 35-42.

Drobysheva, N.V. (2004). Avtoreferat dissertatsii na soiskaniye uchenoy stepeni kandidata filosofskikh nauk [The dissertation author's abstract on competition of a scientific degree of the candidate of philosophical sciences]. In Rostovskii gosudarstvennyi universitet [Rostov State University]. Rostov-na-Donu, $26 \mathrm{p}$.

Drobysheva, N.V. (2013). Tkachestvo - traditsionnyi vid dekorativno-prikladnogo iskusstva v kul'ture narodov Severnogo Kavkaza [Weaving is a traditional kind of arts and crafts applied in the culture of the peoples of the North Caucasus]. In Fundamental'nye issledovaniia [Fundamental research], 8-1, 198-201.

Drobysheva, N.V. (2012). Traditsii dekorativno-prikladnogo iskusstva v kul'ture narodov Severnogo Kavkaza [The traditions of arts and crafts in the culture of the peoples of the North Caucasus]. In Kazanskaia nauka [Kazan Science], 12, 182-184.

Gavrilov, I.K., Batashev, M.S., Makarov, N.P. (2017). Kompleksnaia ekologo-etnograficheskaia ekspeditsiia v Evenkiiu. Priroda i chelovek [Complex ecological-ethnographic expedition in Evenky. Nature and people]. In Severnye arkhivy i ekspeditsii [Northern archives and expeditions], 1 (1), 66-83.

Ivanov, V.Kh. (1999). Etnokul'turnye vzaimosviazi i vzaimovliianie v traditsionnom dekorativnoprikladnom iskusstve korennykh malochislennykh narodov Severo-Vostoka Sibiri [Ethnocultural Interconnections and Interactions in the Traditional Decorative and Applied Arts of Indigenous Peoples of the North-East of Siberia], In Otchet o NIR № 98-06-80179 (Rossiiskii fond fundamental'nykh issledovanii) [Report on Research No. 98-06-80179 (Russian Foundation for Basic Research)].

Kistova, A.V. (2015). Vliianie etnicheskikh migratsionnykh protsessov na samoopredelenie korennykh malochislennykh narodov Sibiri (na primere etnicheskoi gruppy “chulymtsy” Tiukhtetskogo raiona Krasnoiarskogo kraia [Influence of ethnic migration processes on the self-determination of indigenous small-numbered peoples of Siberia (on the example of the ethnic group "Chulymtsy" of the Tyukhtetsky district of the Krasnoyarsk Territory]. In Sovremennye problemy nauki i obrazovaniia [Modern problems of science and education], 1-1, 1885.

Koptseva, N.P. (2013). K voprosu o sokhranenii i vosproizvodstve traditsionnoi kul'tury korennykh malochislennykh narodov Severa, Sibiri i Dal'nego Vostoka v Sibirskom Federal'nom okruge [On the issue of preservation and reproduction of the traditional culture of indigenous small-numbered peoples of the north, Siberia and the Far East in the Siberian Federal District]. In Sotsiodinamika [Sociodynamics], 12, 1-16. 
Korovushkin, D.G. (2017). Boguchanskaia arkheologicheskaia ekspeditsiia IAJeT SO RAN: kratkii istoricheskii ocherk [Boguchansk archaeological expedition of the IAE SB RAS: a brief historical essay]. In Severnye arkhivy $i$ ekspeditsii [Northern archives and expeditions], 1 (2), 23-42.

Koptseva, N.P., Hizhniakova, A.N., Reznikova, K.V. (2017). K voprosu o kontseptakh iazykov korennykh narodov Krasnoiarskogo kraia. In Severnye arkhivy i ekspeditsii [Northern archives and expeditions], 1 (1), 6-22.

Koptseva, N.P., Nevol'ko, N.N., Reznikova, K.V. (2013). Formirovanie etnicheskoi kul'turnoi identichnosti v sovremennoi Rossii s pomoshch'iu proizvedenii natsional'nogo iskusstva (na primere Evenkiiskogo eposa i dekorativno-prikladnogo iskusstva) [Formation of ethnic cultural identity in modern Russia with the help of works of national art (on the example of the Evenki epos and arts and crafts)]. In Pedagogika iskusstva [Pedagogy of Art], 1, 1-15.

Koptseva, N.P., Pimenova, N.N., Seredkina, N.N. (2013). Izuchenie dekorativno-prikladnogo iskusstva i traditsionnykh religii korennykh malochislennykh narodov Severa kak faktor formirovaniia pozitivnoi obshcherossiiskoi kul'turnoi identichnosti [Study of arts and crafts and traditional religions of indigenous minorities of the North as a factor in the formation of a positive all-Russian cultural identity]. In Pedagogika iskusstva [Pedagogy of Art], 2, 15-30.

Krivonogov, V.P. (2017). Natsional'no-smeshannye braki khakasov [National-mixed marriages of Khakassians]. In Severnye arkhivy $i$ ekspeditsii [Northern archives and expeditions], 1 (1), 51-65.

Krmpotich, C., Howard, H., Knight, E. (2016). From collection to community to collections again: Urban Indigenous women, material culture and belonging. In Journal of Material Culture, 21(3), 343-365.

Lesnevskaya, T.I. (2015). Khudozhestvennye narodnye traditsii Severnogo Kavkaza, kak neissiakaemyi istochnik novykh putei i vozmozhnostei $\mathrm{v}$ sovremennom dekorativnom iskusstve [Artistic folk traditions of the North Caucasus, as an inexhaustible source of new ways and opportunities in contemporary decorative art]. In Izvestiia Rostovskogo gosudarstvennogo stroitel'nogo universiteta [Izvestiya of the Rostov State University of Civil Engineering]. 1, 19 (19), 160-163.

Libakova, N.M. (2015). Formirovanie pozitivnoi etnicheskoi identichnosti indigennykh narodov posredstvom dekorativno-prikladnogo iskusstva (rez'ba po kosti) [The formation of positive ethnic identity of indigenous peoples through arts and crafts (bone carving)]. In Sovremennye problemy nauki i obrazovaniia [Modern problems of science and education], 1 (1), 1887.

Libakova, N.M., Kolesnik, M.A., Sergeeva, N.A., Sertakova, E.A. (2017). Issledovatel'skie vozmozhnosti antropologii iskusstva na primere kostoreznykh proizvedenii masterov Sibiri [Research opportunities of anthropology of art on the example of bone carving works of masters of Siberia]. In Sibirskii antropologicheskii zhurnal [Siberian anthropological journal], 1 (1), 22-34.

Mandryka, P.V. (2017). K istorii arkheologicheskogo izucheniia nizov'ev Angary [To the history of archaeological study of the lower reaches of the Angara]. In Severnye arkhivy i ekspeditsii ekspeditsii [Northern archives and expeditions], 1 (2), 43-51.

McGaw, J. (2014). Mapping "place” in southeast Australia: Crafting a possum skin cloak. In Craft Research, 5 (1), 11-34.

Pimenova, N.N. (2016). Mekhanizmy sotsiokul'turnykh izmenenii korennykh malochislennykh narodov Sibiri i Severa: kontseptsiia kul'turnoi travmy P. Shtompki [Mechanisms of sociocultural changes of indigenous small-numbered peoples of Siberia and the North: the concept of cultural trauma P. Shtomki]. In Sotsiodinamika [Sociodynamics], 3, 37-45. DOI: 10.7256/2409-7144.2016.3.18210. 
Pod'iapol'skii, S.A. (2017). Iazykovaia politika i tselostnost' gosudarstva [Language Policy and State Integrity]. In Severnye arkhivy i ekspeditsii [Northern archives and expeditions], 1 (2), 73-82.

Pogodaev, N.P. (2017). Diskussiia o iazyke opisaniia vzaimodeistviia [Discussion on the language of describing the interaction]. In Severnye arkhivy i ekspeditsii [Northern archives and expeditions], $1(2), 52-72$.

Razumovskaia, V.A. (2011). Khudozhestvennyi tekst v reshetkakh kul'tury i perevode [The artistic text in the grids of culture and translation]. In Vestnik Tiumenskogo gosudarstvennogo universiteta. Gumanitarnye issledovaniia. Humanities [Bulletin of the Tyumen State University. Humanities], 1, 206-213.

Razumovskaia, V.A. (2014). Strategiia ostraneniia v perevode "sil'nyh" tekstov russkoi kul'tury [The strategy of elimination in the translation of "strong" texts of Russian culture]. Mundo Eslavo. In Journal of Slavic Studies, 13, 177-192.

Reznikova, K.V. (2017). Sovremennoe sostoianie sel'kupov Krasnoiarskogo kraia po materialam polevykh issledovanii (iiun' 2010 g.) [The current state of the Selkup in the Krasnoyarsk Territory based on field research materials (June 2010)]. In Severnye arkhivy i ekspeditsii [Northern archives and expeditions], 1 (1), 23-40.

Sahu, C.K. (2015). Traditional knowledge on Dhokra craft of Mayurbhanj. International Journal of Conservation Science, 6 (2), 217-222.

Seredkina, N.N., Smolina, M.G., Kistova A.V. (2017). Vliianie eposa na skazki korennykh narodov Severa i Sibiri. In Sibirskii antropologicheskii zhurnal [Siberian anthropological journal], 1 (1), 62-73.

Shmal'ts, M.E. (2017). Migratsionnaia travma kak faktor obedneniia iazykov korennykh malochislennykh narodov Sibiri: primer nizhnekolymskikh iukagirov [Migratory trauma as a factor of impoverishment of the languages of indigenous small-numbered peoples of Siberia: an example of the Lower Kolyma Yukaghirs]. In Sibirskii antropologicheskii zhurnal [Siberian anthropological journal], 1 (1), 43-51.

Sitnikova, A.A. (2015). Korennoe obrazovanie: aktual'noe sostoianie i problemy [Native education: current status and problems]. In Pedagogika i prosveshchenie [Pedagogy and enlightenment], 3, 300311. DOI: 10.7256/2306-434X.2015.3.17048

Sitnikova, A.A. (2017). Retsenziia na kollektivnuiu monografiiu "Korennye malochislennye narody Severa i Sibiri v usloviiakh global'nykh transformatsii”, izdannuiu v Krasnoiarske v 2012 g. [Review on a collective monograph "Indigenous small-numbered peoples of the North and Siberia under the conditions of global transformations" published in Krasnoyarsk in 2012]. In Sibirskii antropologicheskii zhurnal [Siberian anthropological journal], 1 (1), 52-61.

Tzanidaki, D., Reynolds, F. (2011). Exploring the meanings of making traditional arts and crafts among older women in Crete, using interpretative phenomenological analysis. In British Journal of Occupational Therapy, 74 (8), 375-382.

Varavina, G.N. (2016). Ornamental art of the indigenous people of the Arctic: traditions and the present (based on the Evens and Evenki). In Journal of Siberian Federal University. Series: The humanities, 9 (10), 2525-2530.

Vorozhtsova, E.V. (2008). Dekorativno-prikladnoe iskusstvo korennykh malochislennykh narodov Dal'nego Vostoka Krainego Severa i Severo-Vostoka Sibiri v sobranii Sakhalinskogo gosudarstvennogo oblastnogo khudozhestvennogo muzeia [Decorative and applied art of the indigenous minorities of the 
Far East of the Far North and the North-East of Siberia in the collection of the Sakhalin State Regional Art Museum]. In Gumanitarnye issledovaniia v Vostochnoi Sibiri i na Dal'nem Vostoke [Humanitarian research in Eastern Siberia and the Far East], 1, 20-28.

Zamaraeva, Iu.S., Reznikova, K.V., Pimenova, N.N. (2017). Istoriia antropologicheskikh issledovanii korennykh narodov Sibiri [The history of anthropological studies of the indigenous peoples of Siberia]. In Sibirskii antropologicheskii zhurnal [Siberian anthropological journal], 1 (1), 6-21.

\title{
Перспективные форматы развития декоративно-прикладного искусства коренных малочисленных народов Красноярского края
}

\author{
К.В. Резникова, Н.Н. Середкина, \\ Ю.С. Замараева \\ Сибирский федеральнылй университет \\ Россия, 660041, Красноярск, пр. Свободный, 79
}

Статья посвящена анализу современного декоративно-прикладного искусства коренных народов Красноярского края (селькупов, ессейских якутов, ненцев, нганасан, долган) с иелью выявления перспективных форматов развития данной практики культуры. Эмпирические данные были получены с помощью методов включенного наблюдения и экспертного глубинного интервью в ходе полевых исследований в местах компактного проживания коренных народов на территории Красноярского края - в Носке, Фарково, Дудинке, Хатанге, Ессее и др. В результате исследования были выделены основные тенденции современного декоративно-прикладного искусства коренных народов края, связанные, с одной стороньл, с частичным сохранением традиционных видов деятельности (почив одежды, обуви, вышивка бисером), появлением новых практик декоративно-прикладного искусства (выделка шучьих голов), с другой стороны, с утратой знаний, мастерства, традиции передачи умений по изготовлению изделий декоративно-прикладного искусства от поколения к поколению. Кроме того, на основе анализа современной ситуации в области декоративно-прикладного искусства коренных народов Красноярского края был выделен ряд перспективных форматов развития данной практики культуры, как уже используемых коренными малочисленными народами, так и тех, которые могли бы быть эффективно использованы в перспективе.

Ключевые слова: декоративно-прикладное искусство, ненџы, селькупь, долганы, ессейские якутыл, нганасаныл.

Исследование выполнено при поддержке краевого государственного автономного учреждения «Красноярский краевой фонд поддержки научной и научно-технической деятельности» в рамках реализации проекта: "Декоративно-прикладное искусство коренных малочисленных народов Красноярского края: современное состояние, перспективы развития.

Исследование выполнено при финансовой поддержке Российского фонда фундаментальных исследований, Правительства Красноярского края, Красноярского краевого фонда поддержки научной и научно-технической деятельности в рамках научного проекта № 17-16-24601.

Научная специиальность: 24.00.00 - культурология. 